Autor:

Antonio Celso Mendes

Título

\title{
Evolução da Filosofia Jurídica no Brasil
}

Banca Examindoras:

Presidente: Dr. Luiz Fernando Coelho

Dr. Aloisio Surgik

Dr. Sansão José Loureiro

Defesa: $\quad 29$ de novembro de 1989.

\section{Resumo}

Desde a publicação da história das Idéias Jurídicas no Brasil (S.P. Ed. Grijalbo, 1969), de Antonio Luiz Machado Neto, não se contava, afora estudos esparsos, com uma atualização mais sistemática da evolução da filosofia jurídica no Brasil. Tal foi o nosso propósito, ao elaborar dissertação de mestrado junto à Universidade Federal do Paraná, com ênfase na área de Direito Público. Dentre as correntes da jusfilosofia brasileira contemporânea, a dissertação procurou destacar o jusnaturalismo (Machado Paupério, Galvão de Souza), o sociologismo jurídico (Cláudio Souto Machado Neto), o culturalismo (Miguel Reale, Nelson Saldanha) o dogmatismo (Orlando Gomes, Maria Helena Diniz), direito e linguagem (Luiz Alberto Warat, Tércio Sampaio Ferraz Júnior) e a corrente crítica (Roberto Lyra Filho, Luiz Fernando Coelho). Foi por demais gratificante percorrer os fracassos e os sucessos das idéias jurídicas brasileiras, quando em confronto com a contingência histórica e política vivida pelo povo. Como se pode constatar, muitas das idéias sociais e políticas patrocinadas pela intelligentsia brasileira, mesmo brilhantes, não deixaram de refletir certo conservadorismo, contribuindo para a perpetuação de muitos problemas que ainda hoje nos afligem. 